\title{
Endocrine correlates of behavioural oestrus in the female giant panda (Ailuropoda melanoleuca) and associated hormonal changes in the male
}

\author{
Rosemary C. Bonney*, Deborah J. Wood and Devra G. Kleiman $\dagger$ \\ Department of Reproduction, Institute of Zoology, The Zoological Society of London, Regent's \\ Park, London NWI 4RY, U.K. and †National Zoological Park, Smithsonian Institution, \\ Washington DC 20008, U.S.A.
}

\begin{abstract}
Summary. Urinary excretion of oestrogens and androgens by a pair of giant pandas was monitored by radioimmunoassay during behavioural oestrus through two successive breeding seasons. The excretion of oestrogens by the female was at a maximum during the proceptive period and lower during the period of receptivity. In the first breeding season studied, elevated androgen excretion in the male coincided with peak receptivity in the female.
\end{abstract}

The study indicates that accurate timing of natural mating or artificial insemination could be achieved by monitoring oestrogen excretion in the female.

\section{Introduction}

The giant panda (Ailuropoda melanoleuca) is found in the wild at altitudes of $2600-3500 \mathrm{~m}$ mainly in the Szechuan province of China. The rarity of these animals both in the wild and in captivity combined with difficulties inherent in the maintenance and breeding of exotic species in zoos, brings to our attention the extreme endangered status of this species. Peking Zoo has bred a number of animals since 1955 but, with the exception of a recent birth of an infant in Mexico City, which died after a few days, and a pregnancy in Japan terminated by maternal death, attempts elsewhere have been unsuccessful. Survival of the giant panda is therefore likely to depend on the promotion of studies to increase our knowledge of its reproductive biology in order to aid the establishment of successful breeding in captivity. If breeding programmes are to include techniques such as induction of ovulation and artificial insemination, then baseline endocrinological studies must be an essential part of the programme.

Little is known about the reproductive biology of the giant panda except that it is seasonally monoestrous with a short period of oestrus between March and May (Anon, 1974). Pro-oestrus tends to be prolonged as is often observed in other solitary carnivores (Kleiman, Karesh \& Chu, 1979). Information on the oestrous period has so far been derived largely from behavioural studies (Anon, 1974; Kleiman et al., 1979) and hormonal changes have yet to be established.

A pair of giant pandas at the National Zoological Park, Washington, received as a gift from the People's Republic of China have been the subject of behavioural studies since their arrival in 1972. The behavioural aspects of their reproductive development and changes in both the male and the female associated with breeding season and oestrus have been described in detail (Kleiman et al., 1979).

The present study was undertaken to monitor the urinary excretion of oestrogens before and during behavioural oestrus in the female and changes in androgen excretion in the male, at the National Zoological Park, Washington, between February and May in 1979 and 1980.

* Present address: Department of Chemical Pathology, St Mary's Hospital Medical School, London W2 1PG, U.K. 


\section{Materials and Methods}

\section{Animals}

The giant panda pair, the male, Hsing-Hsing, and the female, Ling-Ling, were 8 and $8 \frac{1}{2}$ years of age respectively at the start of the study and were considered to be sexually mature. Management techniques and housing conditions have been described in detail by Collins \& Page (1973) and Melun (1975). These animals were housed separately with the opportunity to interact through galvanized steel-mesh partitions. Introductions were made only during the time of oestrus.

Behavioural observations were conducted with the assistance of trained voluntary observers from the Friends of the National Zoo according to the methods described by Kleiman et al. (1979). The present study, however, reports only the qualitative behavioural changes associated with breeding season and oestrus and their relationship to hormonal measurements.

Early morning collections of fresh urine were obtained daily from both animals by syringe from the cage floor and frozen immediately for transportation to London.

Analyses

Filtered urine samples were analysed by radioimmunoassay and steroid excretion was expressed relative to urinary creatinine concentration. Oestrogens were measured in urine from the female while samples from the male were analysed for androgen excretion. When steroids were extracted from hydrolysed samples with diethyl ether before radioimmunoassay the steroid levels obtained were not significantly different from those measured without extraction (oestrogens: $t=1 \cdot 1$, androgens: $t=0 \cdot 3$, d.f. 18). Assays were therefore performed without extraction.

\section{Urinary creatinine determination}

Urinary creatinine was measured by a modification of the Jaffe reaction (Folin, 1914). Duplicate aliquots $(50 \mu \mathrm{l})$ of urine or standards were dispensed into disposable cuvettes of $1 \mathrm{~cm}$ light path (Hughes \& Hughes Ltd, Romford, Essex, U.K.) together with $3 \mathrm{ml}$ freshly prepared alkaline picrate reagent ( 1 vol. $5 \%$ Triton X-100 in $0.075 \mathrm{~N}-\mathrm{NaOH}: 1$ vol, saturated picric acid: 4 vols deionized distilled water). The cuvettes were covered and allowed to stand for $2 \mathrm{~h}$ to permit colour development. Absorption was then measured at $520 \mathrm{~nm}$ in a Pye Unicam SP15 colorimeter and the results expressed as $\mathrm{mg}$ creatinine $/ \mathrm{ml}$ urine. A standard curve $(0-3 \mathrm{mg} / \mathrm{ml}$ prepared in $0 \cdot 1 \mathrm{~N}-\mathrm{HCl}$ ) was included in each assay.

The inter- and intra-assay coefficients of variation, calculated to be $5.37 \%(n=8)$ and $2 \cdot 10 \%(n=10)$ respectively, were evaluated by duplicate estimations of pooled urine. Samples with a creatinine concentration below the limit of sensitivity of the assay $(0.125 \mathrm{mg} / \mathrm{ml})$ were excluded from the data.

\section{Radioimmunoassay of steroids}

Hydrolysis of urine samples. An aliquot of each urine sample (100 $\mu \mathrm{l})$ was hydrolysed with 0.8 i.u. B-glucuronidase 'Pasteur' (Uniscience) in $100 \mu \mathrm{l}$ phosphate-buffered saline $(0.02$ M-phosphate buffer, $\mathrm{pH} 7.0$, containing $0.2 \% \mathrm{NaCl}$ ) for $1 \mathrm{~h}$ at $37^{\circ} \mathrm{C}$. Each hydrolysed urine sample was then diluted with an appropriate volume of assay buffer $(0 \cdot 1 \mathrm{M}$-phosphate, $\mathrm{pH} 7 \cdot 0$, containing $0.9 \% \mathrm{NaCl}, 0.01 \%$ thimerosal and $1 \%$ gelatin) before radioimmunoassay.

Urinary oestrogens. Urine samples were assayed in duplicate in $12 \times 75 \mathrm{~mm}$ disposable tubes (Luckham Ltd) using an antiserum raised in a goat to oestradiol-17 $\beta, 17$-hemisuccinylbovine serum albumin (Miles Laboratories Ltd, Slough, Bucks, U.K.). The antiserum is reported 
to show complete cross-reactivity with oestrone and oestradiol-17 $\beta$ and the degree of cross-reactivity with oestriol, testosterone and progesterone is stated as $15 \%,<0.2 \%$ and $<0.2 \%$ respectively. The assay therefore gives an estimate of immunoreactive oestrogen.

Each assay tube contained $100 \mu \mathrm{l}$ hydrolysed urine diluted $1: 3$ or $1: 4$ with assay buffer, 100

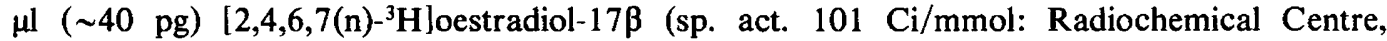
Amersham, U.K.) and $100 \mu \mathrm{l}$ antiserum diluted to give approximately $35 \%$ binding of $\left[{ }^{3} \mathrm{H}\right.$ loestradiol- $17 \beta$ in the absence of unlabelled steroid. A standard curve ranging from 3.9 to $1000 \mathrm{pg}$ per tube was included in each assay. The $50 \%$ level of inhibition occurred at $108.0 \pm 6.0$ (s.e.m.) pg per tube $(n=7)$. Inter- and intra-assay coefficients of variation, calculated to be $10.4 \%(n=8)$ and $8.0 \%(n=10)$ respectively, were evaluated by repeated assay of a urine pool in single and in separate assays.

Each tube was briefly mixed and incubated for $1 \mathrm{~h}$ at $37^{\circ} \mathrm{C}$. Separation of antibody-bound and free steroid was achieved by the addition of $200 \mu$ dextran-coated charcoal suspension $(1.0 \%$ charcoal; Sigma; $0.1 \%$ dextran T-70: Pharmacia) in assay buffer. The tubes were incubated at $0^{\circ} \mathrm{C}$ for $4 \mathrm{~min}$ and centrifuged for $4 \mathrm{~min}$ at $0^{\circ} \mathrm{C}$ and $1750 \mathrm{~g}$. Supernatant $(300 \mu \mathrm{l})$ was removed
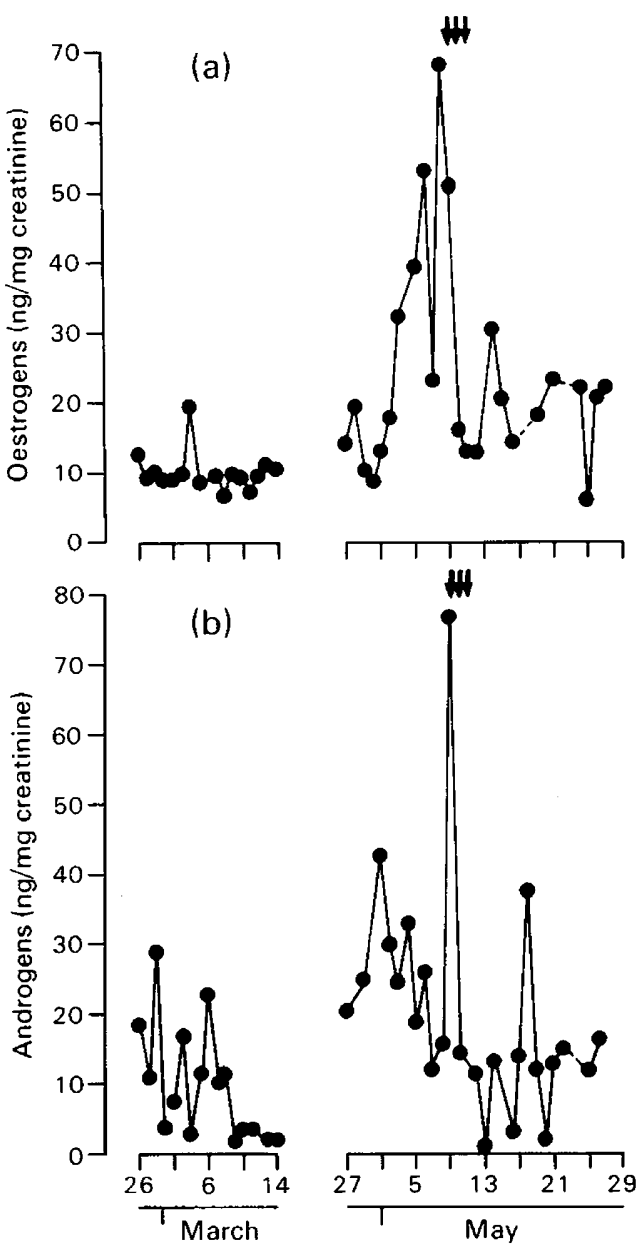

(c)

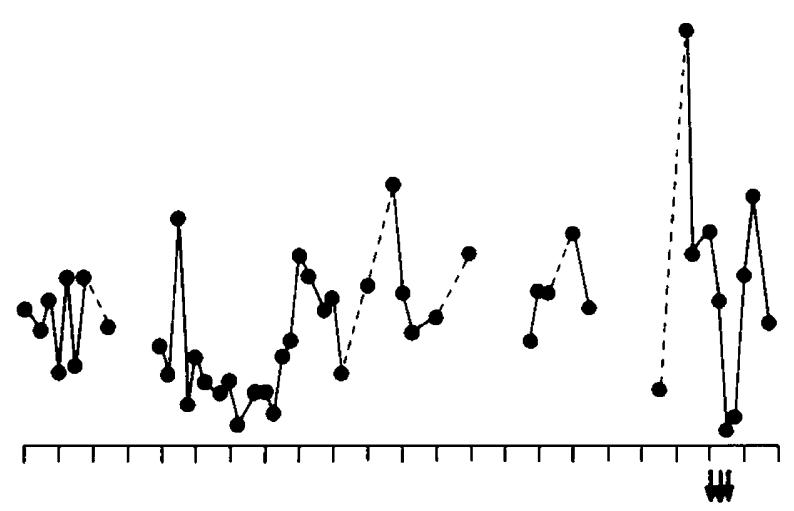

(d)

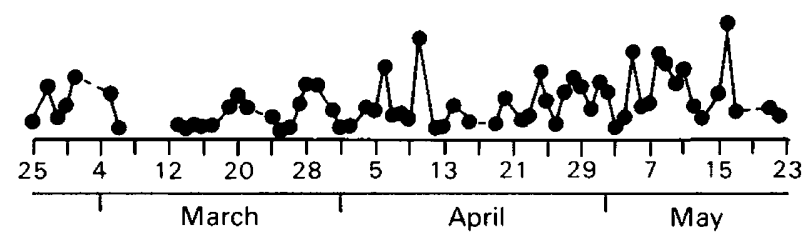

Text-fig. 1. Urinary excretion of oestrogens by the female and of androgens by the male giant panda before and during behavioural oestrus in $1979(\mathrm{a}, \mathrm{b})$ and $1980(\mathrm{c}, \mathrm{d})$. The arrows indicate maximum sexual interaction between the pair. 
to a mini-scintillation vial containing $1 \mathrm{ml}$ scintillant (Picofluor 15: Packard Instruments Ltd) and counted for $3 \mathrm{~min}$ in a Packard 3255 Tri-Carb liquid scintillation spectrometer.

To obtain evidence of the phenolic nature of the material measured by the radioimmunoassay, a hydrolysed aliquot of female giant panda urine was subjected to alkali partition (Engel, Slaunwhite, Carter \& Nathanson, 1950) and the recovery of radioimmunoassay-positive material was compared with that of $\left[{ }^{3} \mathrm{H}\right]$ oestradiol treated in a similar manner. Ether extraction of hydrolysed urine removed $83.0 \%$ of radioimmunoassay-positive material compared with $92.0 \%$ of added $\left[{ }^{3} \mathrm{H}\right.$ ] oestradiol. When the ether extract was treated with $1 \mathrm{~N}-\mathrm{NaOH}, 59.7 \%$ of the radioimmunoassay-positive material and $57.5 \%$ of added $\left[{ }^{3} \mathrm{H}\right]$ oestradiol were transferred to the aqueous layer. Acidification of the alkaline layer and further extraction with ether recovered $82.0 \%$ of radioimmunoassay-positive material and $65.4 \%$ added $\left[{ }^{3} \mathrm{H}\right]$ oestradiol. These data provide evidence for the phenolic nature of the material measured by the radioimmunoassay procedure described above.

Urinary androgens. The antiserum used was raised in a rabbit to testosterone-3(O-carboxymethyl)-oxime-bovine serum albumin (a gift from Dr C. Horth: G. D. Searle \& Co. Ltd, High Wycombe, Bucks, U.K.) and has been reported to cross-react $35.0 \%$ with $5 \alpha$-dihydrotestosterone, $5.1 \%$ with 19 -nortestosterone and $3.4 \%$ with androstenedione (Bonney, Dixson \& Fleming, 1980). The antiserum also cross-reacts $0.3 \%$ with dehydroepiandrosterone, $0.03 \%$ with etiocholanolone and $0.2 \%$ with androsterone.

The assay procedure was identical to that adopted for urinary oestrogens. Each assay tube contained $100 \mu \mathrm{l}$ diluted hydrolysed urine $(1: 3-1: 16), 100 \mu](\sim 60 \mathrm{pg})[1,2,6,7(\mathrm{n})$ ${ }^{3} \mathrm{H}$ ]testosterone (sp. act. $81 \mathrm{Ci} / \mathrm{mmol}$ : Radiochemical Centre) and $100 \mu \mathrm{l}$ antiserum diluted to give approximately $25 \%$ binding of $\left[{ }^{3} \mathrm{H}\right]$ testosterone in the absence of unlabelled steroid. The standard curve ranged from 3.13 to $800 \mathrm{pg}$ per tube and the $50 \%$ level of inhibition occurred at $42.3 \pm 3.7$ (s.e.m.) pg per tube $(n=6)$. Intra- and inter-assay coefficients of variation were $8 \cdot 1 \%(n=10)$ and $9 \cdot 1 \%(n=8)$ respectively as established by repeated assay of a urine pool in a single and in separate assays.

To determine the degree of interference by $3 \alpha$-hydroxyandrogens a sample of urine from the male was assayed before and after treatment with digitonin to remove $\beta$-hydroxyandrogens according to the method of Pearlman, Pearlman \& Rakoff (1954). Digitonin treatment effectively removed $81.9 \%$ of $\beta$-hydroxyandrogens when the recovery of the method $(58.3 \%)$ was taken into consideration.

\section{Results}

As shown in Text-fig. 1(a), basal excretion of immunoreactive oestrogen during February and March 1979 remained essentially constant at approximately $10 \mathrm{ng} / \mathrm{mg}$ creatinine. The onset of behavioural oestrus at the beginning of May was associated with a steady rise in oestrogen excretion. At this time scent-marking and bleating were minimal, there was no loss in appetite and aggressive whining and barking occurred at the approach of the male. On 6 and 7 May scent-marking, bleating and masturbation commenced and appetite was reduced. These behaviours were considerably more intense between 8 and 11 May and were associated with a maximum elevation in oestrogen excretion on 8 May. However, urinary oestrogen concentrations had fallen to baseline levels by 10 May and remained low in association with a decline in oestrous behaviour.

Encounters between the male and the female were permitted once or twice daily between 8 and 11 May. The first encounter was mainly playful but on 9 May interaction increased and vocalization became louder and stronger. The most intense period of interaction occurred on the evening of 10 May when the female presented and displayed lordosis and elicited frequent mounting and thrusting behaviour from the male, which culminated in ejaculation over the back 
of the female. The intensity of sexual activity gradually diminished during the following 2 days and had ceased by 13 May.

Urinary excretion of immunoreactive androgens by the male during the study periods in 1979 is shown in Text-fig. 1(b). Basal excretion of androgens during February and March fluctuated between 2 and $28 \mathrm{ng} / \mathrm{mg}$ creatinine. The onset of sexual activity on 1 May coincided with elevated androgen levels $(42.5 \mathrm{ng} / \mathrm{mg}$ creatinine) and although there was a decline in androgen excretion over the next 7 days, concentrations were still essentially greater than those of the non-breeding season. On 9 May, however, there was a brief but dramatic rise in androgen output ( $77 \mathrm{ng} / \mathrm{mg}$ creatinine) which coincided with the enhanced period of sexual activity. Thereafter, there followed a rapid decline in hormone excretion to non-breeding season levels, interrupted on 18 May by a further brief increase $(37.5 \mathrm{ng} / \mathrm{mg}$ creatinine) which was not sustained.

Between February and May 1980 oestrogen excretion by the female before the onset of sexual activity was more variable than for the comparable period in 1979, with concentrations of oestrogen fluctuating between 10 and $32 \mathrm{ng} / \mathrm{mg}$ creatinine (Text-fig. 1c). Between $15 \mathrm{March}$ and 27 April there was an initial fall in oestrogen excretion to $3-10 \mathrm{ng} / \mathrm{mg}$ creatinine but from 25 March urinary concentrations increased steadily to reach maximum excretion on 12 May. A high concentration of oestrogen was present in the urine on 11 May but creatinine levels were below the detection limit of the assay. Indications of the onset of behavioural oestrus, namely increased activity, scent-marking and reduced appetite were, as in 1979, evident during the first week in May and bleating commenced on 13 May. Unfortunately, however, only limited hormonal data were available for this period. Displays of intense sexual activity comparable to that described for 9-11 May 1979 occurred during encounters with the male between 15 and 17 May 1980 at a time when oestrogen excretion was falling rapidly. Artificial insemination was attempted on 17 May but by this time oestrogen levels had fallen to $<5 \mathrm{ng} / \mathrm{mg}$ creatinine. There was, however, a secondary rise in oestrogen excretion $(35 \mathrm{ng} / \mathrm{mg}$ creatinine) on 20 May. A similar rise followed the maximum period of sexual interaction in 1979.

The excretion of androgens by the male between February and May 1980 is indicated in Text-fig. 1(d). Androgen levels were much lower than during the corresponding period of study in 1979 , ranging from 1 to $16 \mathrm{ng} / \mathrm{mg}$ creatinine and rarely rising above $5 \mathrm{ng} / \mathrm{mg}$ creatinine. On this occasion there was no obvious relationship between androgen concentrations and increased sexual activity.

\section{Discussion}

Although the present data on the urinary excretion of oestrogens by the female and changes in androgen by the male of a pair of giant pandas are limited, they provide an important contribution towards knowledge of the reproductive biology of this rare species.

During 1979 the female showed a striking rise in oestrogen excretion at a time when pro-oestrous behaviours were predominant. These behaviours (scent-marking, bleating and increased activity) have been discussed by Kleiman et al. (1979) and are considered to be directed towards successful establishment of contact with the male and initiation and maintenance of sexual encounters. Within the pro-oestrous phase oestrogen levels rose from 10 to $68 \mathrm{ng} / \mathrm{mg}$ creatinine but at the time of oestrus, during the receptive period of the female, oestrogen excretion declined dramatically and had reached basal concentrations while sexual activity was still evident.

The results of the 1980 study are less clear since it was necessary to exclude data which were below the acceptable limit of the creatinine assay. Although for this reason no information is presented for 11 May the urine analysed nevertheless contained a high level of oestrogen which suggests that oestrogen excretion was elevated on this day. Maximum excretion of oestrogen was 
again associated with pro-oestrus while the most intense period of sexual activity coincided with declining oestrogen excretion.

A similar relationship between oestrogens and the oestrous period has been reported for other carnivores. Wolves, for example, resemble the giant panda in that they are seasonal breeders with a single period of oestrus between late January and early April. Behavioural and endocrine correlates of oestrus in this species have been described by Seal, Plotka, Packard \& Mech (1979) who showed that peak levels of plasma oestradiol coincided with pro-oestrus and declined during oestrus. A similar relationship between hormones, behaviour and the time of ovulation has been reported for the domestic bitch (Wildt, Danko, Chakraborty \& Seager, 1979). Furthermore, in the domestic cat, an elevation in plasma oestrogens precedes oestrus by 1-2 days and is associated with a brief period of proceptive behaviour (Shille, Lundström \& Stabenfeldt, 1979).

In 1979, urinary excretion of androgens by the male giant panda increased dramatically at the time of maximum receptivity of the female. In general, urinary androgen concentrations were higher and much more variable than during the same period of the following year. Furthermore, in 1980 , there was no significant increase in androgen excretion at the peak of female receptivity. Copulatory behaviour and anticipation of copulation have been shown to elevate plasma levels of testosterone in other species, e.g. man (Fox, Ismail, Love, Kirkham \& Lorraine, 1972), rat (Taleisnik, Caligaris \& Astrada, 1966; Purvis \& Haynes, 1974; Kamel, Mock, Wright \& Frankel, 1975), rabbit (Saginor \& Horton, 1968; Haltmeyer \& Eik-Nes, 1969) and bull (Katongole, Naftolin \& Short, 1971). However, the elevation in urinary androgens measured in this study might also be a reflection of adrenal activity as a result of stress and excitement associated with frustration. Such an interpretation is particularly important when the degree of interference by unknown androgens is considered.

The present study indicates that detection of the receptive period of the female giant panda might be successfully accomplished by monitoring the excretion of oestrogens. In this way, accurate timing of natural mating or artificial insemination could be achieved.

We thank W. Xanten, R. M. Bush and K. Kranz for their aid and, especially, Keepers B. Bingham, F. Dreher and E. Jacobs who collected the panda urine over a 2-year period.

\section{References}

Anon (1974) On the breeding of the giant panda and the development of its cubs. Acta zool. sin. 20, 139-147. [Translated by Lois Chang, U.S. National Library of Medicine.)

Bonney, R.C., Dixson, A.F. \& Fleming, D. (1980) Plasma concentrations of oestradiol-17 $\beta$, oestrone, progesterone and testosterone during the ovarian cycle of the owl monkey (Aotus trivirgatus). $J$. Reprod. Fert. 60, 101-107.

Collins, L.R. \& Page, J.K. (1973) Ling-Ling and Hsing-Hsing: year of the panda. Anchor Press, New York.

Engel, L.L., Slaunwhite, W.R., Carter, P. \& Nathanson, I.T. (1950) The separation of natural oestrogens by counter current distribution. J. biol. Chem. 185, 255-263.

Folin, O. (1914) On the determination of creatinine and creatine in urine. J. biol. Chem. 17, 469-473.

Fox, C.A., Ismail, A.A.A., Love, D.N., Kirkham, K.E. \& Lorraine, J.A. (1972) Studies on the relationship between plasma testosterone levels and human sexual activity. J. Endocr. 52, 51-58.
Haltmeyer, G.C. \& Eik-Nes, K.B. (1969) Plasma levels of testosterone in male rabbits following copulation. J. Reprod. Fert. 19, 273-277.

Kamel, F., Mock, E.J., Wright, W.W. \& Frankel, A.I. (1975) Alterations in plasma concentrations of testosterone, LH and prolactin associated with mating in the male rat. Horm. \& Behav. 6, 277288.

Katongole, C.B., Naftolin, F. \& Short, R.V. (1971) Relationship between blood levels of luteinizing hormone and testosterone in bulls and the effects of sexual stimulation. J. Endocr. 50, 457-466.

Kleiman, D.G., Karesh, W.B. \& Chu, P.R. (1979) Behavioural changes associated with oestrus in the Giant panda (Ailuropoda melanoleuca) with comments on female proceptive behaviour. Int. Zoo $\mathrm{Yb}$. 19, 217-223.

Melun, N.C. (1975) Giant panda exhibit at the National Zoological Park, Washington. Int. Zoo Yb. 15, 263-265.

Pearlman, W.H., Pearlman, M.J.R. \& Rakoff, A.E. (1954) Estrogen metabolism in human pregnancy; a 
study with the aid of deuterium. J. biol. Chem. 209, $803-812$.

Purvis, K. \& Haynes, N.B. (1974) Short-term effects of copulation, human chorionic gonadotrophin injection and non-tactile association with a female on testosterone levels in the male rat. J. Endocr. 60, 429-439.

Saginor, M. \& Horton, R. (1968) Reflex release of gonadotrophin and increased plasma testosterone concentration in male rabbits during copulation. Endocrinology 82, 627-630.

Seal, U.S., Plotka, E.D., Packard, J.M. \& Mech, L.D. (1979) Endocrine correlates of reproduction in the wolf. 1. Serum progesterone, estradiol and LH during the estrous cycle. Biol. Reprod. 21, 1057-1066.
Shille, V.M., Lundström, K.E. \& Stabenfeldt, G.H. (1979) Follicular function in the domestic cat as determined by estradiol-17 $\beta$ concentrations in plasma: relation to estrous behavior and cornification of exfoliated vaginal epithelium. Biol. Reprod. 21, 953-964.

Taleisnik, S., Caligaris, L. \& Astrada, J.J. (1966) Effect of copulation on the release of pituitary gonadotrophins in male and female rats. Endocrinology 79, 49-54.

Wildt, D. E., Danko, W.B., Chakraborty, P.K. \& Seager, S.WJ. (1979) Relationship of serum estrone, estradiol-17 $\beta$ and progesterone to $\mathrm{LH}$, sexual behavior and time of ovulation in the bitch. Biol. Reprod. 20, 648-658.

Received 29 April 1981 